\title{
Analysis of French SMEs' International Competitiveness
}

\author{
Alireza Nasiri ${ }^{1}$, Benjamin Sultan ${ }^{2} \&$ Antonio Alleyne ${ }^{2}$ \\ ${ }^{1}$ University of Tehran, Iran \\ ${ }^{2}$ Dalian University of Finance and Economics, China \\ Correspondence: Alireza Nasiri, University of Tehran, Iran. E-mail: anasiri@ut.ac.ir
}

Received: February 9, 2018; Accepted: February 28, 2018; Published: March 14, 2018

\begin{abstract}
The purpose of this study is to determine the causes of reduced competitiveness among French companies. Using a mixed methodology approach of qualitative and quantitative techniques, we surveyed 75 companies from different sectors. According to the analysis, the authors deduced that French SMEs' competitiveness has been declining due to both "price factors" and "non-price factors". The findings have also highlighted a lack of appropriate incentives offered to French SMEs to expand abroad, or to compete at a higher level - for those with a presence spanning borders.
\end{abstract}

Keywords: French SMEs, competitiveness, International Business

\section{Introduction}

In recognition of the significant pace the world economies are changing, the World Economic Forum initiated an inaugural ranking of over 140 countries based on an index (Note 1), published in the Global Competitiveness Report. The report is built on a survey of over 13,000 (Note 2) executives, which measures 101 variables (macroeconomics, standard of living, quality of institutions, technology advancement, etc). It has since been the benchmark for countries to measure the overall competitiveness of companies, both domestic and international.

According to recent reports, the French economy continues to slide down this listing: In 2009, France occupied the $16^{\text {th }}$ spot (World Economic Forum, 2009), in 2010 and 2011, 18 $8^{\text {th }}$ position (World Economic Forum, 2010) (World Economic Forum, 2011), in $201221^{\text {st }}$ (World Economic Forum, 2012), by 2014 and 2015 France had been demoted to the $23^{\text {rd }}$ and $22^{\text {nd }}$ (World Economic Forum, 2015), respectively. This explains why, when elected in 2012, President Francois Hollande made it top priorities to restore French companies to a globally competitiveness scale.

The loss of competitiveness has become a major concern for the France, as the adverse effects on economic growth contributed to an unexpected five years of stagnation for the economy. Restoring competitiveness levels is not only important for improving France's performance in terms of growth and employment, but also in reversing the decline of France's share of world exports (European Union, 2015). French executives are in collective agreement that international competitiveness is crucial to the French economy. Internationalized and innovative competitive small and medium-sized enterprises (SMEs) are necessities for the growth and prosperity of France, as they occupy a significant portion of the total number of companies. In France, SMEs account for $99.6 \%$ of all enterprises and approximately $60 \%$ of the labor force (Eurostat, 2014)According to French Legislation (Note 3), an SME has less than 250 employees; a turnover of below $€ 50$ million and total assets not exceeding $€ 43$ million (KfW Bankengruppe, 2015). It is therefore without question that such companies are significant contributors with regards to the performance of the overall economy.

As the globalization phenomenon continues to grow in relevance, the ability to spread a business abroad has become one of the determining elements to being competitive (Lecerf, 2012). Yet, French SMEs haven't been performing well at this task. In fact, they even underperforming when compared with their European neighbors, particularly Germany. According to the European Commission of 2007, only 8\% of European SMEs engage in international activities (European Commission, 2007). In 2015 a report supporting the view that SMEs are a primary element to the EUs' economic growth, innovation, job creation, and social integration, noted that $32 \%$ of French SMEs engage in cross border trade. However, an overwhelming number $(94 \%)$ of them focused primarily on other European markets. Across the southern European continent, it was also noted that France alongside Germany SMEs are the less likely to export (European Commission, 2015). 
In line with the current research, Hollande's Government first step was to identify the factors which resulted in the reduced placement global competitiveness status; which could provide measures of guidance towards solutions. An initial limitation of this research is that it only covers the global competitiveness of Metropolitan France and its SMEs, excluding the French owned enterprises operating abroad. Moreover, it identifies reasons for this lack of competitiveness, but does not necessarily provide the appropriate solutions. Competitiveness is an important driver of growth for any economy, therefore France must strive to increase the ability of its SMEs to compete internationally, if it is to retain or surpass its previous position on the Competitiveness listing, and maintaining its world power over the long term.

Despite of the importance of this issue to the French economy, a void exists which seeks to identify and understand the causes of the underlining problem. Our research aims to fill this void, and in doing so provide help to the Government of France in their quest for adequate solutions to counter this issue. This work can prove beneficial to other governments having similar competitiveness concerns.

\section{Literature Review and Background}

Research that identifies the causes of the global competitiveness decline in businesses continues to be scarce. According to previous studies, participating in international trade affords SMEs the opportunity to increase resources as they reach new markets; while alleviating undue pressures on domestic financial resources. Access to external financing is also improved through export activities, providing convenient access to new networks of potential investors more willing to participate in innovation efforts (Julien \& Carrier, 2002).

In 1996, Barkema, et al argue that knowledge was the critical to being a successful in the global market place for SMEs (Barkema, Bell, \& Pennings, 1996). The acclamation that previous international knowledge is essential to SME was later contended by Reuber and Fisher (1997).

According to Handfield, et al. (1999), SMEs operating within an industry or with technologically advanced suppliers have higher innovation potential. Subsequent research by de Jong and Vermeulen (2006) added that innovation activities are intensely correlated to the economic sector. There is no shortage of literature which suggests that innovation has an influential and strong relationship with SME performance, directly or indirectly. However in recognition of the impact caused by resource limitations, Wolff and Pett later argued that innovation in SMEs are conditioned by the availability of resources (Wolff \& Pett, 2006).

In light of such constraints, SMEs should seek to get maximum productivity and benefit from the resources available to them. In line with economic principles, firms grow to achieve minimum efficient scale (Mansfield, 1979). Wolff and Pett further posited that SME product improvement has greater influence on growth and profit performance than their process improvements (Wolff \& Pett, 2006)

By 2008, Kierzenkowski evaluated the France's competitiveness noting the country's poor export showing. The author posited that the poor performance was linked to a series factors rather a single cause; suggesting that the deterioration in competitiveness point to what he describe as supply side factors - relative inability of French firms to service foreign markets. Kierzenkowski also argue that deficiency in competitiveness is more often a symptom than the cause of one or more underlying economic weaknesses and that a comprehensive policy response that addresses the sources of the problem is needed. Policies that foster research and development, promote innovation, reducing the financial obligations by way of taxes and creating favourable conditions for improved business growth (Kierzenkowski, 2009).

Through a recent survey of 335 French SMEs, Lecerf provided significant evidence of the interdependence between technological appropriation in internationalized SMEs and business growth. The author posited that engaging in cross-border research and development will contribute to an increase in volume for SMEs; indicating that technological resources is a common driver of international activities. Product development and geographical market expansion is the most valuable strategic combination positively related to research and development (Lecerf, 2012).

\subsection{Review of French SMEs}

In July 2012, the French Prime Minister entrusted Louis Gallois with the task of deriving suggestions to guide the Government's policies in efforts to boost French's competitiveness (Richter, 2012). In November of that year, the 'Rapport sur la compétitivité' report was submitted to the Government. Contained in this report were proposals on how to "remove the brakes on global competitiveness"; identifying solutions without any root causes (Gallois, 2012). This report would later help the French Government create the "National policy for Growth, Competitiveness and Employment." The report sought to bring into law new regulations ultimately designed to benefit French companies by increasing their ability to be innovative and competitive international. The report 
defines competitiveness as: The ability of France to durably improve the quality of living of its inhabitants, with high level of employment and social cohesion, in an improved environment. The economy would be measured by the aptitude of France to maintain and attract activities, and by the ability of companies to face their competitor, foreign and domestics.

Gallois premier focus was on the Industry sector, as it is the one whose competitiveness declined most during the decade recently past. Gallois highlighted that employment in the industry sector has been on a continuous decline, from $26 \%$ of total employment in 1980 (5.1 million workers) to $12.6 \%$ in 2011 ; a loss of 2 million jobs in 30 years. The rise of foreign competitiveness would be responsible for between one-third and one-half between 2000 and 2007 (Richter, 2012). Between 2000 and 2011, France considerable market shares in Europe, which is first commercial outlet to the French. Exports have decreased from 12.7\% to 9.3\% in 2011 (Gallois, 2012).

Other consequence of lost competitiveness was France's trade deficit; shifting from a $€ 3.5$ billion surplus in 2002, to $€ 71.2$ billion deficit over the 9 period - resulting public debt level of almost $100 \%$ of the gross domestic product (GDP) (Gallois, 2012). Gallois therefore proposed 22 propositions (Note 4) which sought to kick-start France's competitive status once again.

In 2013, the OECD (Note 5)published 'FRANCE: Restoring Competitiveness' (Note 6), which identified some of the causes in minor fashion, while primarily seeking to find solutions to restore French companies' competitiveness. Revealing as one possible cause of the declining performance was productivity the report captured and evaluated a range of French companies, not specific to SMEs. It was also indicated that post the global financial crisis, France's hourly labor productivity remained high but income per capita grew slowly. The report shows that France failed to make adequate use of its labor factors, therefore suggesting a need for the Government boost employment rates (OECD, 2013)

Ultimately slow productivity growth causes the loss of market shares, thus deterioration in the trade balance. Despite France's advantages in some sectors such as aerospace and transport, it continues to experience difficulties with exporting sector (OECD, 2013). In addition, the gradual decline of France's competitiveness, with wage increases outpacing productivity has resulted in significant per-unit labor costs. Also mentioned was the high-cost and inefficient service of French facing the stronger international competitor.) (OECD, 2013).

Being solution focused, for both French companies and Government, OECD (2013) documented several proposals on how to support productivity and competitiveness. Proposals included; boost research and innovation - noting that innovative entrepreneurs in France are scarcer than other countries in other OECD member states; a more efficient public sector - exploring ways to reduce regulatory burden; and tax reform policies - huge spending is reflected in a labor-tax "wedge".

The OECD (OECD, 2013) further suggested a reform the existing labour market in light of two challenges; weak employment for the young and old, and protracted and severe unemployment; results of early retirement. On the other hand, due to the lack of skills that young workers possess, their unemployment rate is 2.7 times higher than the rate of older generation. According to Broughton (Broughton, 2011) Training is an issue that has not featured highly in many employers despite being stressed by employer bodies and other organizations, its importance to SMEs, particularly during the crisis times. There is a shortage of vocational training in France and almost all OECD countries (OECD, 2013).

Across various literatures, a number of solutions were offered to aid France's effort to combat the prevailing competitiveness problem. On one hand, it is good to have solutions which can allow French companies to regain competitiveness. On the other hand competitiveness is more often a symptom than the cause of underlying economic weaknesses (Kierzenkowski, 2009), suggesting a better approach is to find the causes to prevent future reoccurrence. Therefore, the authors seek to fill in this gap and provide research that focuses more on finding the reasons rather than blanket solutions causing the competitive decline of French SMEs.

\section{Methodology}

For this research, a mix approach of both quantitative and qualitative techniques of analysis was utilized. For the former, our research requires the study of both micro and macroeconomic variables (e.g. cost, taxes, productivity, etc.) in order to see how these variables affect the competitiveness of SMEs. This will be performed through the use of charts and tables.

Regarding the latter, our research requires the study of current laws and regulations in efforts to evaluate their impact on the growth of the French economy. We also investigated the intentions and motivations of French companies' regarding innovation and internationalization. The data use throughout this research was collected 
from secondary online sources via related publication and public available statistics regarding the France's SMEs and economic structure.

Apart from the collection of secondary data, meaningful information was also acquired from primary sources; using non probability sampling survey approach. Given the limitations in time and resources, it was decided that the purposive method for sampling selection was best suited. The approach was favoured due to the elected small sample size of French SMEs, which was chosen from a selection of thousands of French SMEs listed on one of France's main economic websites (Note 7). Seventy-five SMEs were selected from different sectors.

A questionnaire, which consists of 10 questions related to activities and operations abroad and within the French territory, was design for specific to this research. Questions regarding possible causes responsible for their lack of competitiveness were also included. Emails were sent to all 75 companies, attaching the document and the link to an online designed survey (Note 8), which was written in French. From this sample, 8 companies answered via survey monkey and 35 of them answered in document format and returned via email. A total of 43 replies were therefore collected and analyze. Results are provided in the following sections. Following the receipt of responses, the authors proceeded to build and analyze graphs and charts, to identify and discuss the main causes for the recent lack of competitiveness in French SMEs. This was followed by a review of a series of publicly available business reports for current and past years.

\section{Findings}

The data we collected in our research are presented in diagrams and table formats in the following .

Figure 4.1 indicates that $84 \%$ of the respondents (36 companies) received their revenue primarily from the domestic territory. On the other hand, the remaining minority, which accounted for $16 \%$ (7 companies), revealed that their main source of revenue is from abroad.

\section{Home and abroad Revenue \\ - French Territory $\quad$ Abroad}

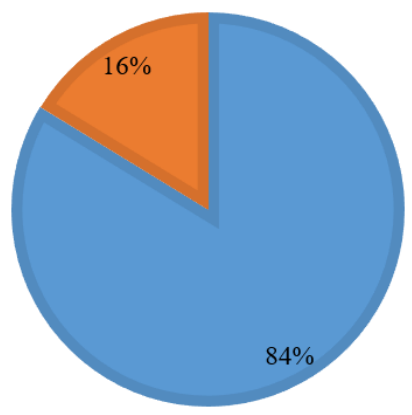

Figure 4.1 French SMEs Revenue Sources from Overseas Operations

Seen in Figure 4.2, $81 \%$ of the sample (35 companies), indicated that their competitors are mainly local companies. The remaining $19 \%$ said that their competitors are foreign.

\section{Main Competitors}

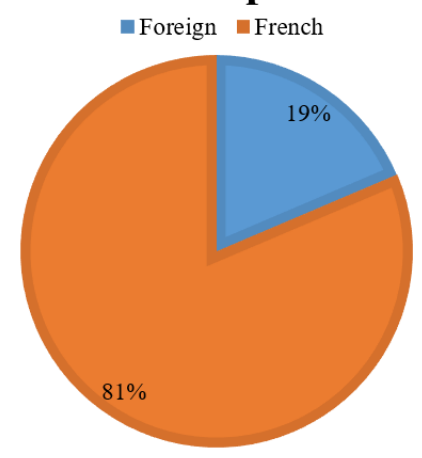

Figure 4.2 French SMEs Main Competitors 


\section{Potential Foreign Markets}

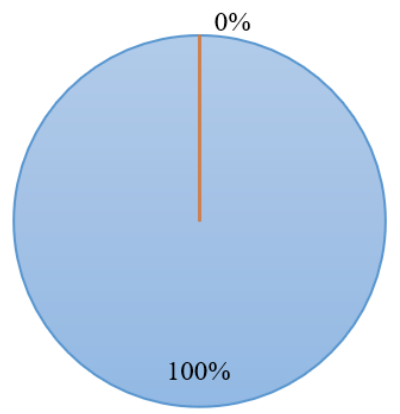

$\square$ Yes $\square$ No

Figure 4.3 Potential Foreign Market for French SMEs Activities or sectors

Illustrated in figure 4.3 all respondents believe that there are potentially viable foreign markets for their companies to do business in their related sectors.

\section{Success Of SMEs in Other Countries}

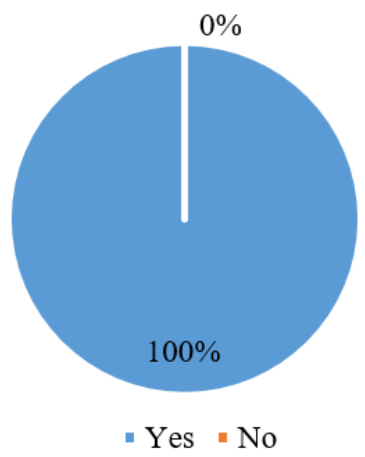

Figure 4.4 French SMEs Success in Global Market

Similar to Figure 4.3, Figure 4.4 displays that the total number of respondents thought that their products/services could be successful in other markets.

\section{Plan For Business Expansion}

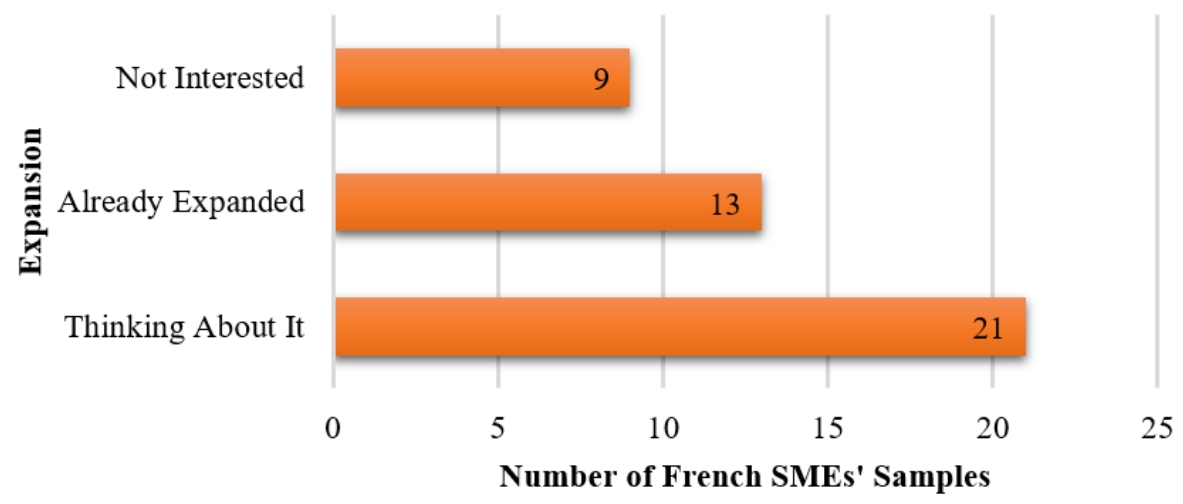

Figure 4.5 French SMEs Plan for Expanding Business in Abroad 
Figure 4.5 shows various answers when asked about expanding their business abroad. The majority, which accounted for 21 respondents, were still contemplating whether they should expand their business. Then, 13 respondents said that they had already expanded, with the remaining minority of 9 respondents demonstrated no interest in expanding abroad.

\section{Reluctant To Expand Activities Abroad}

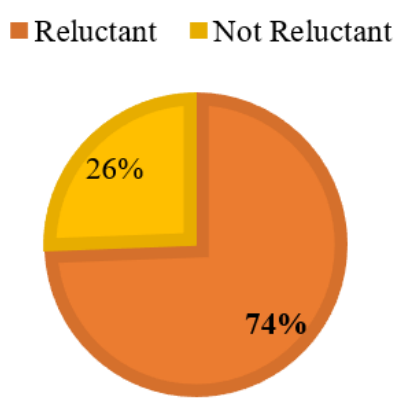

Figure 4.6 French SMEs Reluctant about Expanding Activities Abroad

Figure 4.6 depicts $74 \%$ of respondents (32 respondents) are reluctant about expanding their activities abroad. While the other $26 \%$ of them thinks that they are not reluctant about expanding their activities abroad.

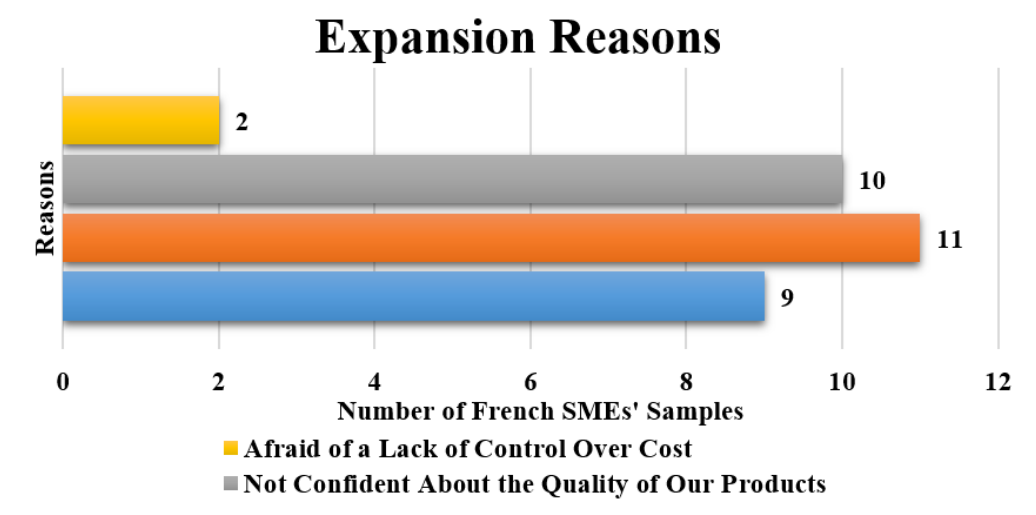

Figure 4.7 Reasons French SMEs Reluctant to Expand Business in Abroad

Figure 4.7 above is linked directly to the answers on Figure 4.6. Among 74\%that said yes, 34\% thought that there are too many strong competitors abroad; while $31 \%$ indicated a lack of confidence in the product's quality. A noticeable $28 \%$ of respondents confirmed limited knowledge of doing business internationally. Lastly, remaining respondents expressed fear in the lack of control over cost they expect to have.

\section{Big Negative Impact On}

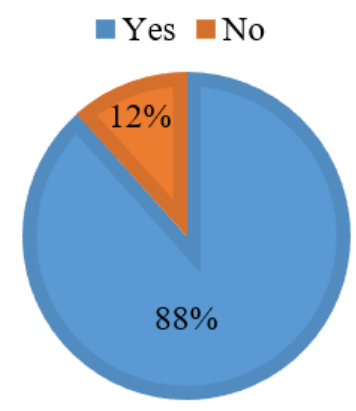

Figure 4.8 Negative Impact of 2008 Economic Crisis on French SMEs 
Figure 4.8 provides evidence that $88 \%$ of the sample felt that the 2008 crisis had a big negative impact on their business. Meanwhile, $12 \%$ felt that the 2008 financial crisis impact was negligible to no impact.

\section{Fully Recovered from Crisis}

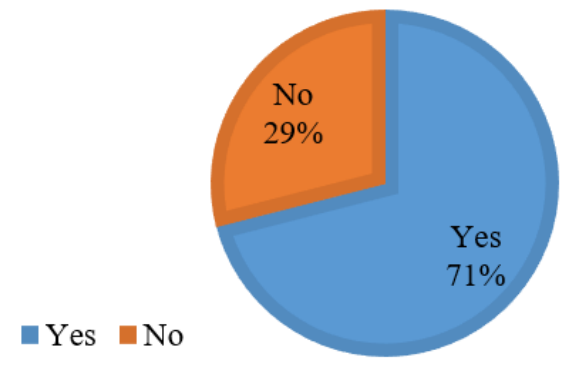

Figure 4.9 Recovery of French SMEs from 2008 Economic Crisis

The results in Figure 4.9 directly related to Figure 4.8. From the respondents that indicated that the 2008 financial crisis heavily impacted business, $71 \%$ of them also noted that they had subsequently reached full recovered prior to the issuance of the survey. Meanwhile, 29\% of them said that they were yet to reach pre-crisis operations.

Table 4.1 (below) elaborates on the findings presented in Figure 4.1; it shows some stated factors that prevent the surveyed SME's from reaching a higher level of competitiveness. Each factor was assigned scores depending on the severity (high to low) the impact. Four (4) points were assigned for those who chose the "extremely high impact" option and down to 1 point for those who chose "negligible impact". The table below shows the calculated results. The higher the score, the greater the expected impact the factor is likely to have on the company's competitiveness.

Table 4.1 Factors that have negative impact on competitiveness

\begin{tabular}{|c|c|c|c|c|c|}
\hline \multirow[b]{2}{*}{ FACTORS } & \multicolumn{4}{|c|}{ Number of companies per level of impact } & \multirow[b]{2}{*}{$\begin{array}{l}\text { TOTAL } \\
\text { SCORE }\end{array}$} \\
\hline & $\begin{array}{l}\text { Extremely } \\
\text { High (4 } \\
\text { points) }\end{array}$ & $\begin{array}{l}\text { High } \\
(3 \\
\text { points })\end{array}$ & $\begin{array}{l}\text { Medium } \\
\text { (2 } \\
\text { points) }\end{array}$ & $\begin{array}{l}\text { Negligible } \\
\text { (1 points) }\end{array}$ & \\
\hline Cost of Energy & 0 & 0 & 35 & 8 & 78 \\
\hline Cost of Labors & 9 & 25 & 6 & 3 & 126 \\
\hline $\begin{array}{l}\text { Regulation About the Maximum Number of } \\
\text { Hours/Employee/ Week }\end{array}$ & 9 & 20 & 8 & 6 & 118 \\
\hline Taxes & 4 & 18 & 15 & 6 & 106 \\
\hline Wariness of Banks About Lending to SMEs & 8 & 19 & 10 & 6 & 115 \\
\hline $\begin{array}{l}\text { Government's Inefficient Decision Making } \\
\text { about Meaningful Reforms }\end{array}$ & 1 & 15 & 18 & 9 & 94 \\
\hline
\end{tabular}

Factors With Negative Impact

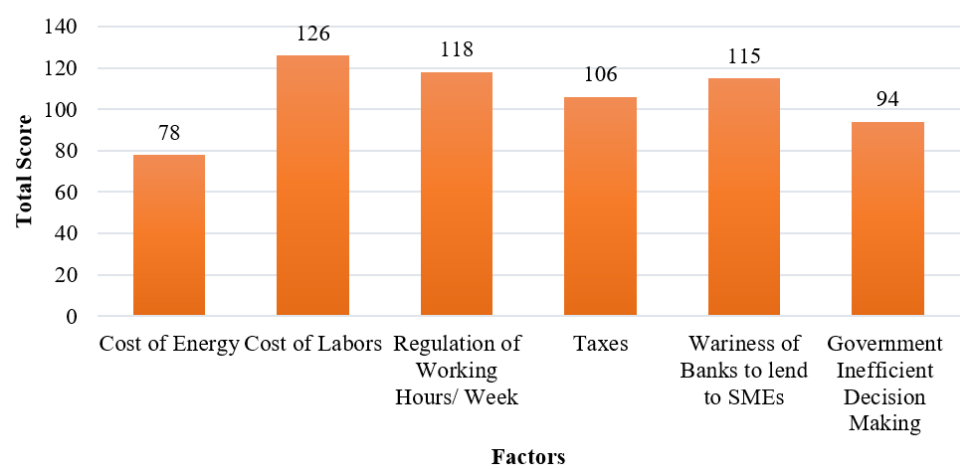

Figure 4.10 Factors with Negative Impact on French SMEs Competitiveness 
Figure 4.10 shows that most companies ranked the cost of labors as the largest impact factor to competitiveness, followed by regulation of working hours, wariness of banks, taxes and government inefficient decision making, in that order. On the other hand, most of SMEs felt that the cost of energy have the least impact for their company to be competitive; ranking all responses between medium and negligible impacts.

\section{Discussion}

Seen from Figure 4.1, 84\% of surveyed SMEs indicated that a significant portion of revenues are derived domestic business activity. For most SMEs in France, operations abroad represent a minor portion of their business and as a result a similar size in the company's revenue generation.

It can be reasoned, that as most SMEs operate within French boundaries, intra-sectoral SMEs will face intense competition amongst themselves. Notably, all SMEs in the survey unanimously admitted to the possibility of success within foreign markets (Asia, Eastern Europe, South America, Africa) for their products and or services (Figures 4.3 and 4.4). Thus, signifying that opportunities abroad for French SMEs have yet to be seized; possibly not even attempted.

The question must therefore be asked - Does the French SMEs possess the desire to seize such opportunity? It turns out that $74 \%$ of surveyed SMEs are reluctant about expanding their operations across borders (see Figure 4.6). The principle reasons being this reluctance being the fear of further competition (see Figure 4.7).

Considering a sizable number of respondents admitted to the direct competition which may lie abroad, comparably, the specialization levels of the French industries bare significant similarities to other nations, such like Germany. Excluding a few 'niches', France is well positioned to develop mid-range products with regards to quality and innovation; whereas the Germany economy may hold the comparative advantage on higher-end products. Differentiating factors of the French economy exposes it considerable price competition from producers abroad. Noting that emerging countries-including Southern and Eastern Europe - operate at a production-costs well below the cost generated in by SMEs in France. This is an issue of concern when comparing with industries based in India, Brazil, Mexico, Poland, Czech Republic, or even Spain. To operate at the level of global competitors, French SMEs must find method to reduce their production costs while improving the production capacity.

It is rationally assumed that the majority of SMEs are lacks confidence in the quality of their products to face international community. However, coupled with a limited capacity to provide internal financing, the expansion of business operations for French SMEs are severely hampered. As a consequence, French SMEs are not only challenged by external sources, they possess insufficient fiscal space which would allow for any major attempts at innovation that would ultimately result in increased productivity. For these reasons, French SMEs continues to loose "ground" regarding price and non-price (Note 9) competitiveness compared with other economies. French SMEs, and thus the French industries, have not been able to enhance the quality of their products (moving from mid-range to high-end); with possible exceptions of specialized and narrow fields of the luxury, aeronautics, nuclear and pharmaceutical industries.

Given, the limited number of SMEs engaged in cross border activities, it can be proposed that French executives often lack the necessary skills and/or knowledge required for international environment. This also limits the possibility of successfully navigating a company in a brutally competitive global business environment. This is not to understate the unforeseen (natural or otherwise) challenges businesses are likely to face during regular operations.

The impact of the 2008 financial crisis can be consider as one of the causes which may have led to the deterioration of competitive levels in French SMEs; and indeed, such assumptions can be supported by the results of Figure 4.8. Approximately $90 \%$ of the respondents indicated that the crisis has brought with it significant adverse effects to their business. Worthy of note are the many SMEs were force into closure, reduce staff complement, or found themselves financially strained. Even though these reasons would be have been sufficient to justify the lack of competitiveness; six (6) years following- in 2014- $71 \%$ of the surveyed SMEs have fully recovered (Figure 4.9). Thus, full blame for the lack of competitiveness cannot rest primarily on the 2008 financial fallout. What are the other factors which could have deteriorated the ability of French SMEs to compete internationally?

In figure 4.10, SMEs ranked a number of factors depending on how important their impact would be, on their ability to be competitive. Logically, the cost of energy had the lowest score among all, as the price of electric energy in France is price relatively low for industries. France's nuclear plants are the most advanced in the world, and thus represent a perceived competitive advantage, that is very important as a possession. Similar sentiments can be express for infrastructure and public services, which are also rated as high-quality. They are today considered as attractive and productivity factors. 
The factor identified with the largest influence was cost of labor. Indeed, France has one of the unit per labour cost is among the most expensive in Europe. The minimum wage in France is regarded as also one of the highest in all of Europe. Labor cost accounts for a large portion of SME's spending, particularly since unit labor costs have been rising faster than the rate of the country's GDP. This also presents another reason why, SMEs are required to reduce margins, creating additional financial easing to increase innovation efforts (i.e self-financed ventures)

Another factor of significance consideration would be regulation regarding maximum work-hours per week. Commonly referred to as the " 35 hours law", this law states that -unless it is mentioned otherwise in the job contract- any hour worked subsequent to 35 hours in one week will be regarded as overtime and paid in accordance. Obviously, this number of hours is relatively low, when compared to other countries around the world. The productivity of French workers, working only 35 hours per week limits the profitable capacity (Note 10) of French SMEs. Moreover, a considerable portion of workers usually work more than 35 hours per week, thus increasing the already burdensome labour cost; coupled with those imposed by the government.

Recognized as one of the most heavily taxed economies in the world, French SMEs and entrepreneurs have continued to complain, following decades of raised concerns. Cleary noticeable are the expenses faced by small business owner to hire staff, as in addition to the required monthly taxes paid for every employee, employers are also mandated to pay a tax every time an individual is hired for a long-term contract. Employers are required to pay the equivalent of around $50 \%$ of their employees' salary per month (OECD 2013), which sometimes undermine the ability of an SME to make surplus economic profits.

Additional sentiments expressed by SMEs as a partial cause of the country's reduced competitiveness level was the instability and inefficiency in the Government's decision making. Classifying the French economy as overregulated, while often making unstable decision, local SMEs stressed continuous "harassment" by the Government. Indicating that decisions made by the Government regarding SMEs are often divisive; conflicts the desires of employers and employees.

Worthy of note is that French SMEs, compared with their European counterparts, suffer from restrained access to credit. According to the OECD (OECD, 2013), banks exhibit a reluctant nature to invest in SMEs for international expansion or R\&D purposes. As a result, in $2010, R \& D$ spending by the French represented a marginal $1.4 \%$ of the GDP, compared to $1.9 \%, 2.7 \%$ and $2.3 \%$ for German, Finnish and Swedish companies, respectively. In addition, very few SMEs have access to private sector credits. France possesses an ability to create companies; however those that fail to grow, due to this lack of credits from both banks and crowd investors (OECD, 2013).

A vicious cycle exists, where the lack of innovation and international specialization lead to small profit margins and reduces investments, therefore leading to smaller innovation; and the cycle continues.

\section{Conclusion}

The majority of France's SMEs operate within the French territory, therefore narrowing their revenue stream mainly from domestic sources, while seeking to escape greater from abroad. Therefore suggesting that French companies have been "sitting too long in their comfort zones" leaving them only to compete among themselves, rendering them unable to take advantage of several possibilities within the global marketplace; i.e. increase consumer base and additional revenues. However, until now they still have failed to express the desire to seize such opportunities. It is the authors' contention that the reluctance to expand abroad, while staying confined to the French borders, has in-part led to the lack of competitiveness in France's SMEs.

Among French SMEs lies a persistent fear to penetrate foreign markets. However, small number the country's SMEs has taken the initiative to expand across borders, with another small number willing to compete internationally. These efforts are greatly hampered by a lack of international business knowledge, low confidence about their products and the existence of experienced competitors that greatly reduce their ability to survive internationally. Additionally, France's mid-range products have yet to compete with other countries', such as Germany that offers high-end products; why India and Mexico who offer similar product quality for a lower price. For this reason, French products may be less attractive in the global market. The lack of innovation and high production-costs has lead France's SMEs to lose their competitiveness.

Recognition was also given to the effects of the 2008 financial crisis, which brought severe hardship the entire French business community. However, despite significant, recovery most SMEs continue to suffer from the lack of competitiveness.

Law-related factors which undermine the competitiveness of French SMEs have also been identified. The most significant being expensive wage and labour cost, which outweighs productivity growth. Other factors include " 35 hours law", the high tax rate and the wariness of bank to lend money to SMEs, all of which limits the capacity to 
invest in R\&D. New companies require capital to grow their business and to be more competitive; however the French SMEs may not be offered the appropriate levels of assistance.

\section{Recommendations}

France undoubtedly has some assets; one of a fine quality of life, quality infrastructures, and a leading position in some industries (pharmaceutical, aeronautics, transport, luxury, food industry). At first glance, it would be easy to vision the success of France in its attempt to acquire international competitiveness; given the necessary resources and facilities are mobilized to reach the desired objective. Yet, the question remains - are required resources being mobilized appropriately? Results suggest otherwise. In effort to foster better competitive SMEs in France, a number of underlying concerns should be addressed, by way if a strong partnership between the Government and the SME business community.

As a primary objective, steps should be taken to build producer confidence in the products offered. Despite being an internal issue, Government's assistance can be offered through campaigns that focus on building local pride. Similar steps can also be taken for the education of internationalization of business; inclusive of discussion fora between domestically based SMEs, successful multinational corporations and Government with a purpose not only to inform by to facilitate the potential competitive firm that lack the desire or knowledge operate across borders. The establishment of a service, which supports and facilitates first time expanded could critical to the success of the SMEs in the global marketplace.

There is also the concern of excessive legislation, termed as burdensome taxation and unbalanced employment laws by the SME and entrepreneurs community. It is clear that greater dialogue is needed between the French Government and the domestic business community in the formulation of appropriate policy. To address current concerns, bilateral discussion can be held between both parties with a mutual objective of finding best policy mix that benefits both the private and public sector. Slight restructuring of existing policy may be required.

Lastly, providing SMEs with easier access to credit would allow them to increase efforts in R\&D while providing a stimulus to boost their innovative capacity. Government's contribution can come by way of the establishment of a special fund dedicated for this purpose, by simply acting as a guarantor for those SMEs, which were evaluated to be internationally competitive and are seeking to expand. Alternatively, many local investors or households in France are willing to diversify their investment portfolios. Providing them with SME-investment options would prove beneficial both parties; bringing funds to the SMEs while giving investors the ability to diversify through small revenue generating companies. A high innovative capacity may lead to increase productivity and higher profit returns, subsequently reducing the burden of high labor cost and the possibility of reoccurring need for financial assistance.

\section{References}

Barkema, H., Bell, J., \& Pennings, J. (1996, February). Foreign Entry, Cultural Barriers, and Learning. Strategic Management Journal, 17(2), 151-166. https://doi.org/10.1002/(SICI)1097-0266(199602)

Broughton, A. (2011, June 23). SMEs in the crisis: Employment, industrial relations and local partnership. Retrieved July 25, 2015, from European Foundation for the Improvement of Living and Working Conditions (Eurofound). Retrieved from http://www.eurofound.europa.eu/observatories/eurwork/comp arativeinformation/smes-in-the-crisis-employment-industrial-relations-and-local-partnership

de Jong, J., \& Vermeulen, P. (2006). Determinants of Product Innovation in Small Firms. International Small Business Journal, 24(6), 587-609. https://doi.org/10.1177/0266242606069268

European Commission. (2007). Supporting the Internationalisation of SMEs. Report Final of the Expert Group. Enterprise and Industry Directorate General, Entrepreneurship Unit. Brussels, Belgium: European Commission.

European Commission. (2015). Annual Report on European SMEs 2014 / 2015: SMEs start hiring again. Directorate-General for Internal Market,I ndustry, Entrepreneurship and SMEs. Brussels: European Commission. https://doi.org/10.2873/886211

European Union. (2015). Eurostat Statistics Explained. Retrieved September 23, 23rd September 2014, from http://ec.europa.eu/eurostat/statistics-explained/index.php/Statistics_Explained

Gallois, L. (2012). (2012) Rapport sur la competitivite. Paris: Premier Ministre. Retrieved September 24, 2014, from http://fichier.europe1.fr/infos/rapport_de_louis_gallois_sur_la_competitivite.pdf

Handfield, R. B., Ragatz, G. L., Petersen, K. J., \& Monczka, R. M. (1999). Involving Suppliers in New Product 
Development. California Management Review, 42(1), 59-82.

Julien, P., \& Carrier, C. (2002). Innovation et PME. In P. Julien (Ed.), Les PME: Bilan et perspectives (3rd ed.). Cap-Rouge (Québec): Presses Inter-Universitaires.

KFW Bankengruppe. (2015). SME Investment and Innovation: France, Germany, Italy and Spain. Maisons-Alfort Cedex: Bpifrance. $\quad$ Retrieved from https:/www.kfw.de/PDF/DownloadCenter/Konzernthemen/Research/PDF-Dokumente-Studien-und-Materialien/SME-Investment-andInnovation-October-2015.pdf

Kierzenkowski, R. (2009). The challenge of restoring French competitiveness. ECD Economics Department Working Papers,(720). Retrieved from http://dx.doi.org/10.1787/222054166088

Lecerf, M. A. (2012, June). Internationalization and Innovation: The Effects of a Strategy Mix on the Economic Performance of French SMEs. International Business Research , 5(6). https://doi.org/10.5539/ibr.v5n6p2

Mansfield, E. (1979). Microeconomics (3rd ed.). New York: Norton.

OECD. (2013). France: Restoring Competitiveness. Paris: OECD Publishing. https://doi.org/10.1787/9789264207967-en

Reuber, A., \& Fisher, E. (1997). The influence of the Management Team's International Experience on the Internationalization Behaviors of SMEs. Journal of International Business Studies, 28(4), 807-805.

Richter, W. (2012, October 26). Competitiveness Cacophony: Attack On France's Sacred Cow . Retrieved July 24, 2015, from Wolf Street Howling about Business and Finance: http://wolfstreet.com/2012/10/26/competitiveness-cacophony-attack-on-frances-sacred-cow-2/

Wolff, J. A., \& Pett, T. L. (2006, March). Small-Firm Performance: Modeling the Role of Product and Process Improvements. Journal of Small Business Management, 44(2), 268-284. https://doi.org/10.1111/j.1540627X.2006.00167.x

World Economic Forum. (2009). The Global Competitiveness Report 2009-2010. Geneva: World Economic Forum. Retrieved from http://www3.weforum.org/docs/WEF_GlobalCompetitivenessReport_2009-10.pdf

World Economic Forum. (2010). The Global Competitiveness Report 2010-2011. Geneva: World Economic Forum. Retrieved from http://www3.weforum.org/docs/WEF_GlobalCompetitivenessReport_2010-11.pdf

World Economic Forum. (2011). The Global Competitiveness Report 2011-2012. Geneva: World Economic Forum. Retrieved from http://www3.weforum.org/docs/WEF_GCR_Report_2011-12.pdf

World Economic Forum. (2012). The Global Competitiveness Report 2012 - 2013. Geneva: World Economic Forum. Retrieved from http://www3.weforum.org/docs/WEF_GlobalCompetitivenessReport_2012-13.pdf

World Economic Forum. (2015). The Global Competitiveness Report 2015-2016. Geneva: World Economic Forum. Retrieved from http://www3.weforum.org/docs/gcr/2015-2016/Global_Competitiveness_Report _20152016.pdf

\section{Notes}

Note 1. Global Competitiveness Index

Note 2. From 2010 the list has growth to 13,500

Note 3. Law for the Modernisation of the Economy (LME) introduced in 2008.

Note 4. Those propositions will not be discussed in this paper, as they do not identify causes for the decline of competitiveness, but solutions.

Note 5. OECD (Organization for Economic Co-operation and Development) aims to promote better policies for better lives and works with 34 members, key partners and over 100 countries.

Note 6. Worthy of note, the OECD 2013 report deals with the general French company, and not specifically SMEs. Yet, SMEs account for more than $99.6 \%$ of the total number of companies in France.

Note 7. http://www.boursorama.com

Note 8. http://www.surveymonkey.com (https://www.surveymonkey.com/s/SSNGWKC)

Note 9. Includes; R\&D, innovation processes, product and service quality, etc.

Note 10. produced surplus for the purpose of export 


\section{Copyrights}

Copyright for this article is retained by the author(s), with first publication rights granted to the journal.

This is an open-access article distributed under the terms and conditions of the Creative Commons Attribution license (http://creativecommons.org/licenses/by/4.0/). 